\title{
25 Research Soure \\ Choosing the best embryogenesis medium in carrot by data mining technology
}

Masoumeh Fallah Ziarani

Shahid Beheshti University

Masoud Tohidfar ( $\nabla$ m_tohidfar@sbu.ac.ir)

Shahid Beheshti University

Mohammah Hosein Mirjalili

Shahid Beheshti University

Hassan Ahmadi Gavlighi

Tarbiat Modares University

Mohsen Hesami

University of Tehran

Original Article

Keywords: artificial neural network, Data Mining, micropropagation, RBF model, carrot

Posted Date: August 11th, 2020

DOI: https://doi.org/10.21203/rs.3.rs-54641/v1

License: (9) (1) This work is licensed under a Creative Commons Attribution 4.0 International License. Read Full License 


\section{Abstract}

Plant cell, tissue and organ culture (PCTOC) is extensively used to propagate faster and more plants, to produce virus-free plants, and secondary metabolites production as well. This requires the optimization of PCTOC conditions for each plant and final aim. Optimizing the micropropagation is time-consuming and costly, because it is different from the plant and even for each variety. In addition requires the optimization of the concentration and type of hormone and the type of explants for each variety in the stages of callogenesis, embryogenesis, shooting and rooting. Hence, today researchers have used Data Mining with using an artificial neural network (ANN) to predict the best conditions for tissue culture and saved time and money considerably. In this research, radial basis function (RBF) model was used to predict the best conditions for carrot tissue culture and the results showed that the highest and the least sensitivity were related to variety and percentage of Agar in liter, respectively. The results prediction of the RBF model showed that the percentage of embryogenesis was $62.5 \%$, but the percentage of embryogenesis in laboratory obtain $75 \%$. The results showed that the RBF model is a good model to predict the results.

\section{Introduction}

Plant biological systems are considered by non-linear and non-deterministic developmental processes. The main factors during control of developmental patterns in these complex systems are environmental and genetic (1). These two key factors contain a high level of inconsistency among and in them that ultimately causes a unique developmental process. A similar condition can be seen in plant tissue culture. The conventional analytical techniques for modeling the growth and development in in vitro culture are costly and time-consuming and sometimes become ineffective because of the existing complex system. Therefore, to circumvent these two main limitations (cost and time) during in vitro culture, computational strategies that can consider the growth kinetics together with thermodynamic constraints of culture conditions are required (2). Many factors such as macro nutrients, micronutrients, plant growth regulators, varieties, different stages of growth plant are effective in tissue culture. In preliminary studies for development of new tissue culture media, combinations or concentration of micro nutrients and macro nutrients were changed. This process is costly and time-consuming $(3,4,5)$.

Recently Multilayer Perceptron (MLP) and neuro-fuzzy logic were used for modeling and predicting in vitro culture process such as shoot proliferation of Prunus rootstocks $(1,6)$, in vitro rooting of Prunus rootstocks (7), in vitro sterilization of chrysanthemum (8), predict the effect of medium macro- nutrients on in vitro performance of pear rootstocks (OHF and Pyrodwarf) of pear (9), prediction and optimization of the plant hormones concentration and combinations for in vitro proliferation of Garnem ( $\times$ N15) rootstock of Vegetative (1), in vitro rooting and acclimatization of Vitis vinifera L. (10). Different artificial neural networks (ANNs) such as MLP, Generalized Regression Neural Network (GRNN), Probabilistic Neural Network (PNN) and Radial basis function (RBF) can be used to interpret and process different data. However, there is no report for using RBF in plant tissue culture. RBF is a three layered feed-forward network type applicable to various regression and classification problems (10).

Research showed that the RBF model has better performance than that of the investigated constitutive equation (lower RMSE) (11). There is an excellent fit between the predicted and experimental flow curves in using the 
developed RBF model. This together with very low RMSE value showed the robustness of the developed RBF model to predict the best media culture of the tested (11).

Tissue culture medium must be optimized because the currently used media culture like MS for all plants and explant is not suitable. There are many optimization algorithms; one of which is a Genetic Algorithm (GA) (12).

Researches indicate GA is a powerful tool for optimized designing culture media for proliferation and by using different amounts of ingredients for predicting the micropropagation.

Today, vaccine production is very important in the world. Carrots as a candidate plant for the production of vaccines and recombinant proteins (13).

Carrots (Daucus carota $\mathrm{L}$ ) grown around the world and this vegetable is is one of the popular root vegetables (13). Carrots are a rich source of minerals, antioxidants and dietary fiber (13). Due to the above reasons, it is necessary to optimize carrot tissue culture with maximum efficiency.

For regeneration of carrot, plant regulatory growth (BAP, 2,4-D, NAA, kin), explants (root, shoot, hypocotyl, leaf), Variety and macro nutrients and micro nutrients effects on regeneration of carrot. The effects of all these elements are effective on the embryogenesis of carrot.

Somatic embryogenesis of plants, as a key character of in vitro propagation, is a difficult and complex process ref. The embryogenesis process is reported to be affected by various factors ranging from endogenous levels of biochemical components such as plant growth regulators to physical conditions. In this study, we employed a data mining strategy using RBF to assess the effect and importance of plant tissue media composition in the embryogenesis of carrot.

\section{Materials And Methods}

\section{Data}

In the first step, several datasets were selected from the previous reports. $(14,15)$. In summary, the datasets include different carrot varieties (Monarch, Nantes improved, Tam Tam, Vilmorn, US- Harumakigosum, US- Haru+ A85 makigosum), different concentration of 2,4-D, BAP, kin and several essential mineral elements which were used as inputs (Table 1).

\section{Radial basis function (RBF)}

Radial-based radial function networks have a wide range of applications including function approximation, time series prediction, classification and system control $(16,17,18)$.

The RBF network has three layers including input layer, a nonlinear hidden layer and a linear output layer. The input can be modeled as a vector of real numbers $X \otimes R n$. The network output is a scalar function of the input vector, $\ell: R n \rightarrow R$, and is calculated whit: 


$$
\ell\left(X \sum_{i=1}^{N} \alpha \mathrm{i} \rho\left(\left\|\mathrm{X}-C_{i}\right\|\right)\right.
$$

The aim is to obtain the most important parameters after initial review of the parameters.

In this research, inputs layers of RBF model were three different concentrations of Plant Growth Regulators (2,4$\mathrm{D}, \mathrm{BAP}, \mathrm{kin})$, three different concentrations of three ions including $\mathrm{MgSO}_{4}, \mathrm{CaCl}_{2}, \mathrm{MnSO}_{4}$ and six varieties of carrot including Monarch, Nantes improved, Tam Tam, Vilmorn, us- Harumakigosum and us- Haru + A85 makigosum. Output was embryogenesis. For this purpose, $75 \%$ data were used as training and $25 \%$ data were used as testing. Also the K- Fold Cross Validation used for the data of this experiment is $5(K=5)$. $R^{2}$ (coefficient of determination), RMSE (root mean square error) and MBE (mean bias error) were used to assess the appropriateness of the RBF model (18) as follows:

$$
\begin{gathered}
\mathbf{R}^{2}=\left(\frac{n\left(\sum x y\right)-\left(\sum x\right)\left(\sum y\right)^{\text {si }}}{\sqrt{\left[N \sum x^{2}\right.}-\left(\sum x\right)^{2}\left[n \sum y^{2}-\left(\sum y\right)^{2}\right.}\right. \\
\text { RMSE }=\sqrt{\left(\sum_{\mathrm{i}=1}^{\mathrm{n}}(\mathrm{M}-\mathbf{0})^{2}\right.} / \mathbf{n} \\
M B E=\frac{\sum_{i=1}^{n}\left(Z_{i-} o_{i}\right)}{n}
\end{gathered}
$$

\section{Genetic Algorithm Optimization}

Genetic Algorithm (GA) is a very powerful tool used to optimize data. This algorithm is a parallel iterative optimization algorithm that has the capability of learning and iteratively for steps such as evolution, selection, mutation and crossover. The evaluation criterion is obtained in order to optimize each value individually.

For obtaining the best fitness, the roulette wheel method was used to select the best population. 100 initial populations, 1000 repeats, the 0.7 mutation rate and 0.05 combination rate were set. The compound function and the mutation function used in this experiment, are respectively Two- Point Crossover and Uniform.

The optimal values of inputs containing varieties, MgSO4, $\mathrm{CaCl} 2$, MnSO4, 2, 4-D, BAP, Kin were determined to achieve the best amount of output (embryogenesis) by GA.

\section{Sensitivity Analysis}

Sensitivity analysis was performed to determine which input parameters have the most impact on the output model. In fact, sensitivity analysis determined which of the input parameters, including the variety, ions including $\mathrm{MgSO}_{4}, \mathrm{CaCl}_{2}, \mathrm{MnSO}_{4}$ and plant growth regulatory including 2,4-D, BAP and kin most effective for obtaining the 
highest amount of embryogenesis. Sensitivity of output vs. input variables is determined by the variable sensitivity error (VSE) value.

VSE indicates the performance of the developed RBF model when all data are not available and the VSR specifies a relative indication between the ANN model error and the VSE if all variables are available. The variables are ranked by VSR and the more important variable has higher value of VSR. This analysis shows which variable was more important than the other parameters for embryogenesis.

\section{Validation experiments}

In order to confirm the results of data validation test, the laboratory test based on RBF-GA was performed. In this research, varieties, different concentrations of ions including MgSO4, CaCl2, MnSO4, 2, 4-D, different concentrations of plant growth regulatory including 2, 4-D, BAP, Kin for predicted- optimized for plant growth regulatory and mineral nutrient.

For this experiment select 8 candidate treatments (table 2) and 4 different explants, including root, shoot, leaf and nodal used for research and used variety was Nantes.

The statistical analysis was performed by ANOVA that based experiments were on Completely Randomized Design (CRD) with 3 replications. Data were analyzed using SPSS software and significantly different means were identified using Tukey's test $(P=0.05)$.

\section{Result}

\section{ANN MODELING AND OPTIMIZATION, AND SENSITIVITY ANALYSIS}

\section{ANN Modeling and Evaluation}

Results of estimation of predicted outputs whit ANN model showed that there is a significant difference between observed and predicted growth factor in both training and test sets (Table 3). Simple regression lines represent a high correlation between the value of the observations and the predicted data values of ion compound, plant growth regulatory concentration, six types of variety and three types of media culture for both the training and testing sets. Using high squared correlation coefficients fitting method and according to the ANN models obtained, the graph was created for presentation the variation in ion compounds, plant growth regulatory concentration, six types of variety and three types of media culture (Fig. 1). The correlation coefficients $\left(R^{2}\right)$ for training data and testing data were 0.833 and 0.666 respectively. RMSE and MBE in training data were 7.879734 and 0.311607 respectively, and in testing data were 10.23974 and 3.78125 respectively. As can be seen RBF model is sufficient accuracy, because correlation coefficients for the validation data set is sufficient. As can be seen, the model is able to predict embryogenesis $\left(R^{2}=0.833\right)$ (Table 3) (Fig. 1).

Based on the results of the research, the ANN can be considered as one of the most effective methods for analyzing the data obtained from tissue culture (embryogenesis) parameters to predict the optimization factors that required at proliferation stage.

\section{Model Optimization and Sensitivity Analysis of the Models}


The ANN- GA Predicted Optimized Amounts of Variable Parameter (effect of mineral nutrients and a plant growth regulator, variety and tissue culture media). The result of optimization show in Table 4 . The results indicate that best variety used in this experiment of between six varieties was Nantes improved. The other of the data is shown in Table 4.

The result of analysis, sensitivity indicated that the higher sensitivity regarding to variety and shorter sensitivity regarding to the percentage of Agar in liter (Table 5).

The results of confirmation analysis showed that the combination of NAA-GA is an efficient method for prediction and optimization of elements combination in in vitro embryogenesis in shoot explant.

The results of NAA- GA model was confirmed in the laboratory. The highest embryos created in the MS media containing $195.23 \mathrm{mg} / \mathrm{l} \mathrm{MgSO}{ }_{4}, 330.07 \mathrm{mg} / \mathrm{I} \mathrm{CaCl}_{2}, 18.3 \mathrm{mg} / \mathrm{I} \mathrm{MnSO}{ }_{4}$ and containing plant growth regulators containing $0.46 \mathrm{mg} / \mathrm{I}$ 2,4- D, $0.03 \mathrm{mg} / \mathrm{I} \mathrm{BAP}$ and $0.88 \mathrm{mg} / \mathrm{l} \mathrm{kin}$ (Fig. 2). The shoot explants were best explants (Fig.3). Percentage of embryogenesis by RBF model have been predicted $62.5 \%$, but percentage of embryogenesis in the laboratory obtain 75\% (Table 5, Fig. 3).

The embryogenesis were formed five weeks after tissue culture of explants. The results of the analysis indicated that used of 8 treatments for embryogenesis of explants root, leaf and shoot at the $5 \%$ level was significant, but with used nodal explants, embryogenesis is not signed by the used treatment and is meaningless (Fig. 3).

\section{Discussion}

Designing a new media culture for tissue culture requires a lot of time and cost, Because many factors such as the type and concentration of hormones, the type and amount of ion, varieties, etc. should be tested alone and in combination with together. There are many studies in which a large number of factors have been used to design a new culture medium. This design is different for any plant and even any variety $(19,20,21,22,23)$.

To solve these problems, the Data Mining as a new method has been proposed. In this method, previous research data are used and the data collected are analyzed in the software and the appropriate model and the best components are obtained in order to produce a new media culture.

In this work, we used NAA- RBF model, as a new data mining technique, in order to achieve a better understanding of the effect of mineral nutrients and a plant growth regulator (2-4-D, BAP and kin), variety (Monarch, Nantes improved, Tam Tam, Vilmorn, US- Harumakigosum, US- Haru + A85 makigosum) and tissue culture media (MS, MSm (mineral salts medium) and B5) on carrot embryogenesis, and to obtain new insights into cure carrot culture media composition. Several types of data obtain from previous observations and analyzed. Good models were simultaneously obtained for the studied parameters. High squared correlation coefficients between predicted and experimental values for all training data demonstrate the exactitude of the models in explaining modifications in the results as a result of variations in the inputs studied (variety, ion and plant growth regulatory concentration and media culture). Some of the data mining effect on micropropagation of Prunus species was investigated by scientists.

The RBF model indicate the highest embryogenesis created in the MS medium containing $195.23 \mathrm{mg} / \mathrm{l} \mathrm{MgSO}{ }_{4}$ $330.07 \mathrm{mg} / \mathrm{I} \mathrm{CaCl}_{2}, 18.3 \mathrm{mg} / \mathrm{l} \mathrm{MnSO}_{4}$ and containing plant growth regulators containing $0.46 \mathrm{mg} / \mathrm{l} 2,4-\mathrm{D}$, 
$\mathrm{MgSO}_{4}, \mathrm{CaCl}_{2}$ and $\mathrm{MnSO}_{4}$ are macroelements nutrient. These elements essential for growth of explant in tissue culture (6).

The results of the RBF model in the laboratory showed a high dependence between RBF model and laboratory results. The correlation between the result of RBF model and the result of the laboratory were $67 \%$.

Magnesium is an essential component of the chlorophyll molecule and is also required nonspecifically for the activity of many enzymes, especially those involved in the transfer of phosphate. In plant, magnesium ion is mobile and serves as a cation balancing and neutralizing anions and organic acids. Very often $\mathrm{MgSO}_{4}$ is used as the unique source of both magnesium and sulphate ions (6).

Concentration of $\mathrm{MgSO}_{4}$ in MS media culture is $370 \mathrm{mg} / \mathrm{l}$ and in MSm media culture is $180 \mathrm{mg} / \mathrm{l}$. Rabiei et al., (2010) shows MSm media culture better than MS for embryogenesis of carrot (15). Walker and Sato (1981) found there to be a large reduction in the number of somatic embryos formed from Medicago sativa callus when $\mathrm{Mg}^{2+}$ was omitted from the medium. observed in tissue culture of melon that the highest level of magnesium occurred in direct somatic embryogenic cultures (25).

Calcium functions as a cofactor with many enzymes and is particularly important in cell wall synthesis. Calcium deficiency may result in shoot tip necrosis. Calcium used in plant tissue culture is mostly in the forms of calcium chloride. Ca influence cellular $\mathrm{pH}$ and a regulator in the source, sink translocation of Carbohydrates too (26).

shows between of 5 concentrations of $\mathrm{CaCl}_{2}(0.1,1,3,6$ and $9 \mathrm{mM}), 9 \mathrm{mM}$ is best effective on callus growth (26).

Concentration of $\mathrm{CaCl}_{2}$ in $\mathrm{MS}$ medium culture is $400 \mathrm{mg} / \mathrm{l}$ and in $\mathrm{MSm}$ media culture is $332.02 \mathrm{mg} / \mathrm{l}$. Rabiei et al., (2010) shows MSm media culture better than MS for regeneration of carrot (15).

Manganese (Mn) as a cofactor is required by some enzyme reactions, particularly in respiration and photosynthesis processes. Mn usually added to the medium in the form of manganese sulfate.

Sarropoulou et al., 2017 shows at $200 \mu \mathrm{M} \mathrm{MnSO}_{4}$ doubled the number of embryogenesis compared to the control.

Concentration of $\mathrm{MnSO}_{4}$ in $\mathrm{MS}$ medium culture is $22.3 \mathrm{mg} / \mathrm{l}$ and in $\mathrm{MSm}$ media culture is $16.9 \mathrm{mg} / \mathrm{l}$. Rabiei et al., (2010) shows MSm media culture better than MS for regeneration of carrot (15).

2,4-D is a type of auxin that necessary for inducing callus. Results show high concentrations of 2,4-D can block normal embryo development $(27,28,29)$ and High concentrations of 2, 4-D can be cause disruption of natural genetic processes and physiological processes. $(30,31,32,33)$. study shows application of $22.5 \mu \mathrm{M} 2,4-\mathrm{D}$. At Glycine max L. effect on embryo morphology and development (36). Result indicate shows High concentration of 2,4-D $(68 \mu \mathrm{M})$ cause morphological abnormalities in the resulted plants (37). But another study shows positive effect of 2,4-D on somatic embryogenesis of Arabidopsis (38). I another study positive effect somatic embryogenesis in a carrot cell suspension culture (39). 
Kinetin is a type of cytokinin, a class of plant hormone that promotes cell division. Kinetin is often used in plant tissue culture for inducing formation of callus (in conjunction with auxin) and to regenerate shoot tissues from callus (with lower auxin concentration). study shows highest embryogenesis obtain used of $5 \mu \mathrm{M}$ kinetin in Coffea (canephora of species of coffee) (40). In contrast with researchs another study shows highest somatic embryogenesis obtain of $50 \mu \mathrm{M}$ of NAA in lulo (Solanum quitoense Lam.).

6-Benzylaminopurine, benzyl adenine, BAP or BA is a first-generation synthetic cytokinin that elicits plant growth and development responses, setting blossoms and stimulating fruit richness by stimulating cell division. The result of research shows that application 1, 5 and $15 \mu \mathrm{M}$ benzyladenine (BA) reveal Somatic embryogenesis Desmocladus flexuosus (34). result shows highest somatic embryogenesis obtain of $4.4 \mu \mathrm{M} 6$ benzylaminopurine (BAP) in A. archeri and A. Appressipila from the hypocotyls explants (35). Sane et el., in 2012 shows for somatic embryogenesis $0.5 \mathrm{mg} / \mathrm{I}$ BAP is needed (2).

Interestingly, we found here that variety was the most important effect for embryogenesis and in fact the model confirms that Nantes improved have highest embryogenesis. Originally, results offered by the RBF model agree with those previously found after a traditional statistical analysis, suggesting the effect of variety is strong (15). Research shown efficient media culture for embryogenesis was MSm medium. The result of the RBF model and traditional statistical analysis is similar and confirmed that the RBF model is appropriate for predicted of embryogenesis (15). In this study, RBF clearly has pinpointed the effect of parameters on the specific growth parameter (embryogenesis).

The work reported in this article illustrate a data mining strategy coupled whit ANN technologies as an additional, novel and accurate approach to evaluate the effect of several growth conditions (in this case, ion and plant growth concentration, variety and media culture) on plant growth. This technology is amazingly useful in identifying interaction effects. It is shorter time consuming and higher helpful because of varying types of data and historical data can be analyzed as well.

ANN- RBF model allows us to answer questions about a useful combination of the element to obtain the best results. This could be so useful for designing new and effective optimization experiments. In the end, the knowledge generated in this research can be simplified increased by including additional information (inputs and outputs) in the previous research results, such as ion and plant growth regulators, variety and plant media culture as they become available.

\section{Conclusion}

In this study, Data Mining used to making tissue culture easier and reduce the cost. The model used to be RBF. By Using this model we can measure the effect of different factors on tissue culture and the results showed that this model is a very suitable model for predicting effects of different factors on tissue culture. We examined embryogenesis of carrot in this study and in the future, this model can be used to study the effect of different factors on other aspects of tissue culture.

\section{Declarations}

\section{Ethics approval and consent to participate}


I agree this section

\section{Consent for publication}

It is not publicly available.

\section{Availability of data and material}

Data and material is available

\section{Competing interests}

There is no competition of interests

\section{Funding}

Not applicable' for that section

\section{Authors' contributions}

Not applicable' for that section

\section{Acknowledgements}

Not applicable' for that section

\section{References}

1. Arab M-M, Yadollahi A, Shojaeiyan A, Ahmadi H (2016) Artificial Neural Network Genetic Algorithm as powerful tool to predict and optimize in vitro proliferation mineral medium for $\mathrm{G} \times \mathrm{N} 15$ rootstock. In Plant Science 8:1853

2. Gago J, Perez- Tornero O, Landin M, Burgos L, Gallego P P (2011) Improving knowledge of plant tissue culture and media formulation by neurofuzzy logic: A practical case of data mining using apricot databases. Journal of Plant Physiology. 2011; 168: 1858-1865

3. Gautheret JR (1939) Sur les possibilite de realiser la culture indefinite des tissues de tubercules de carotte. Compt Rend Acad Sci Paris 208:118-121

4. White PR (1943) Nutrient deficiency studies and an improved inorganic nutrient medium for cultivation of excised tomato roots. Growth 7:53-65

5. Nitsch JP, Nitsch C (1956) Auxin- dependent growth of excised Helianthus tissues. Am J Bot 43:839-851

6. 10.3389/

Arab MM, Yadollahi A, Shojaeiyan A, Ahmadi H. Artificial neural network genetic algorithm as powerful tool to predict and optimize in vitro proliferation mineral medium for G × N15 rootstock. Front. Plant Sci. 2016; 7 : 1526. doi: 10.3389/ fpls. 2016. 01526

7. Arab M, Yadollahi A, Eftekhari M, Ahmadi H, Akbari M, Sarikhani Khorami S (2018) Modeling and Optimizing a new culture medium for in vitro rooting of $\mathrm{G} \times \mathrm{N} 15$ prunus rootstock using artificial Neural NetworkGenetic algorithm. Scientific Reports 8:9977 
8. Hesami M, Naderi R, Tohidfar M. Modeling and Optimizing in vitro sterilizationof chrysanthemum via Multilayer Perceptron- Non-dominated Sorting Genetic Algorithm-II (MLP-NSGAII). In Plant science. 2019; doi: 10.3389/fpls.2019.00282

9. Jamshidi S, Yadollahi A, Ahmadi H, Arab MM, Eftekhari M. Predicting in vitro culture medium macronutrients composition for pear rootstocks using regression analysis and neural network models. Front. Plant Sci. 2016; 7: 274. doi: 10. 3389/ fpls. 2016. 00274

10. Gago J, Landin M, P-Gallego P (2010) A neurofuzzy logic approach for modeling plant processes: A practical case of in vitro direct rooting and acclimatization of Vitis vinifera L. Plant Science 179:241-249

11. Rakhshkhorshid M (2017) A robust RBF- ANN model to predict the hot deformation flow curves of API X65 pipeline steel. Iranian Journal of Materials Forming 4:12-20

12. Wang Y, Shen Y, Zhang X, Gui G, Sun J (2018) An Improved Non- Dominated Sorting Genetic Algorithm-II (INSGA-II) applied to the design of DNA codewords. Math Comput Simul 151:131-139. doi:10.1016/j.matcom.2018.03.011

13. Elizabeth M-E, Dania G-A, Marisela H, Jacquelynne C, Jorge S-G, Andrea R-M, Gabriela R, Teresa G, Gladis F, Edda S, Sergio R-M. Towards the development of an oral vaccine against porcine cysticercosis: expression of the protective HP6/TSOL18 antigen in transgenic carrots cells. Planta. 2015

14. Markus H, Arnd S (1998) Transformation and regeneration of carrot (Daucus carota L.). Molecular Breeding 4:119-127

15. Rabiei K, Polyakov A, Khodambashi M, Sharafova O, Kalashnikova E, Hooshmand S, Omidi M (2010) Carrot (Daucus carota L.) in vitro regeneration. Vegetable Crops Research Bulletin 73:73: 13-22

16. Broomhead DS, Lowe D. Radial basis functions, multi-variable functional interpolation and adaptive networks. Technical report. 1998; RSRE. 4148

17. Broomhead DS, Lowe D (1998) Multivariable functional interpolation and adaptive networks. Complex Systems 2:321-355

18. Schwenker F, Kestler H-A, Palm G. Three learning phases for radial-basis-function networks. Neural Networks 2001; 14: 439-458. CiteSeerX 10.1.1.109.312. doi:10.1016/s0893-6080(01)00027-2

19. Hildebrandt AC, Riker AJ, Duggar BM (1946) The influence of the composition of the medium on growth in vitro of excised tobacco and sunflower tissue cultures. Am J Bot 33:591-597

20. De Fossard RA, Myrint A, Lee ECM (1974) A broad spectrum tissue culture experiment with tobacco (Nicotiana tabacum) pith tissue callus. Physiol Plant 30:125-130

21. Perez T-O, Burgos L (2000) Different media requirements for micropropagation of apricot cultivars. Plant Cell Tissue Org Cult 63:133-141

22. Niedz RP, Evens TJ (2007) Regulating plant tissue growth by mineral nutrition. In Vitro Cell Dev Biol- Plant 43:370-381

23. Petri C, Scorza R (2010) Factors affecting adventitious regeneration from in vitro leaf explants of "Improved French" plum, the most important dried plum cultivar in the USA. Ann Appl Biol 156:79-89

24. Ahmadi H, Golian A (2011) Response surface and neural network models for performance of broiler chicks fed diets varying in digestible protein and critical amino acids from 11 to 17 days of age. Poult Sci 90:2085-2096. doi:10.3382/ps. 2011 - 01367

Page $10 / 18$ 
25. Woll SL, Cooper DJ (1997) Pattern- based closed- loop quality control for the injection molding process. Polym Eng Sci 37:801-812. doi:10.1002/pen

26. Cook DF, Ragsdale CT, Major RL (2000) Combining a neural network with a genetic algorithm for process parameter optimization. Eng Appl Artif Intell 13(00):391-396 doi: 10.1016/ S0952-1976) 00021-X.

27. 10.1016/

Sadeghi BHM (2000) ABP- neural network predictor model for plastic injection molding process. J. Mater. Process. Technol. 2000; 103, 411-416. doi: 10.1016/ S0924- 0136 (00) 00498- 2

28. Chen CR, Ramaswamy HS (2002) Modeling and optimization of variable retort temperature (VRT) thermal processing using coupled neural networks and genetic algorithms. J Food Eng 53(01):209-220 doi:

10.1016/S0260-8774) 00159-5

29. zhang ChowTT, Lin GQ, Song Z (2002) C.L. Global optimization of absorption chiller system by genetic algorithm and neural network. Energy Build 34:103-109

30. Gago J, Landin M, Gallego PP (2010a) Artificial neural networks modeling the in vitro rhizogenesis and acclimatization of Vitis vinifera L. J Plant Physiol 167:1226-1231 doi: 10.1016/ j. jplph. 2010.04.008

31. Gago J, Martinez- Nunez L, Landin M, Gallego PP (2010b) Artificial neural networks as an alternative to the traditional statistical methodology in plant research. J Plant Physiol 167:23-27.

doi:10.1016/j.jplph.2009.07.007

32. Gago J, Martinez L, Landin M, Flexas J, Gallego PP Modeling the effects of light and sucrose on In Vitro propagated plants: a multiscale system analysis using artificial intelligence technology. PLOS ONE 9. 2014; e85989. doi:10.1371/Journal.pone.0085989

33. Park J, Sandberg IW (1991) Universal Approximation Using Radial-Basis-Function Networks. Neural Comput 3(2):246-257. doi:10.1162/neco.1991.3.2.246. Retrieved 26 March 2013

34. Colbourn E, Rowe RC. Neural computing and pharmaceutical formulation. New York: Marcel Dekker. $2005 ;$ P. 145-57

35. Bishop CM (1995) Training with noise is equivalent to Tikhonov regularization. Neural Comput 7(1):108116

36. Zheng ouW, Tao Z. An efficient learning algorithm for improving generalization performance of radial basis function neural networks. Neural Neworks. 2000; vol. 13, no. 4,5

37. Polak E (1971) Computational Methods in Optimization. A Unified Approach. Academic Press., New York

38. Jorge G, Olaya PT, Mariana L, Lorenzo B, Pedro PG (2011) Improving knowledge of plant tissue culture and media formulation by neurofuzzy logic: A practical case of data mining using apricot databases. Journal of Plant Physiology 168:1858-1865

39. Keramat R, Aleksey P, Mahmood K, Olga S, Elena K, Saadollah H, Mansour O (2010) Carrot (Daucus carota L.) iv vitro regeneration. Vegetable Crops Research Bulletin 73:13-22

40. East B (1939) Mean annual hours of sunshine and the incidence dental caries, American. J Public Health 29:777-780

41. Gowri M. Improved carrot and celery cultivars through biotechnology. Horticulture Australia Ltd. 7341 1266

\section{Tables}


Table 1. Differential factors of the carrot embryogenesis

Page 12/18 


\begin{tabular}{|c|c|c|c|c|c|c|c|c|}
\hline \multirow[t]{2}{*}{ Variety } & \multirow{2}{*}{$\begin{array}{l}\text { Agar } \\
\text { (g) }\end{array}$} & \multicolumn{3}{|c|}{ Ion Composision (mg/l) } & \multirow[t]{2}{*}{ 2,4-D } & \multirow[t]{2}{*}{ BAP } & \multirow[t]{2}{*}{ KIN } & \multirow[t]{2}{*}{ Embryogenesis } \\
\hline & & $\mathrm{MgSO}_{4}$ & $\mathrm{CaCl}_{2}$ & $\mathrm{MnSO}_{4}$ & & & & \\
\hline Monarch & 5 & 370 & 440 & 22.3 & 0.2 & 0.2 & 0 & 6.7 \\
\hline Monarch & 5 & 370 & 440 & 22.3 & 0.2 & 0 & 0.2 & 44.3 \\
\hline Monarch & 5 & 370 & 440 & 22.3 & 0.5 & 0.5 & 0 & 3.3 \\
\hline Monarch & 5 & 370 & 440 & 22.3 & 0.5 & 0 & 0.5 & 30 \\
\hline Monarch & 5 & 370 & 440 & 22.3 & 1 & 1 & 0 & 0 \\
\hline Monarch & 5 & 180 & 440 & 22.3 & 1 & 0 & 1 & 22.4 \\
\hline Monarch & 5 & 180 & 332.02 & 16.9 & 0.2 & 0.2 & 0 & 6.7 \\
\hline Monarch & 5 & 180 & 332.02 & 16.9 & 0.2 & 0 & 0.2 & 56.6 \\
\hline Monarch & 5 & 180 & 332.02 & 16.9 & 0.5 & 0.5 & 0 & 6.7 \\
\hline Monarch & 5 & 180 & 332.02 & 16.9 & 0.5 & 0 & 0.5 & 40 \\
\hline Monarch & 5 & 370 & 332.02 & 16.9 & 1 & 1 & 0 & 3.3 \\
\hline Monarch & 5 & 370 & 332.02 & 16.9 & 1 & 0 & 1 & 30 \\
\hline Nantes improved & 5 & 370 & 440 & 22.3 & 0.2 & 0.2 & 0 & 6.7 \\
\hline Nantes improved & 5 & 370 & 440 & 22.3 & 0.2 & 0 & 0.2 & 53.3 \\
\hline Nantes improved & 5 & 370 & 440 & 22.3 & 0.5 & 0.5 & 0 & 10 \\
\hline Nantes improved & 5 & 370 & 440 & 22.3 & 0.5 & 0 & 0.5 & 43.3 \\
\hline Nantes improved & 5 & 180 & 440 & 22.3 & 1 & 1 & 0 & 3.3 \\
\hline Nantes improved & 5 & 180 & 440 & 22.3 & 1 & 0 & 1 & 36.7 \\
\hline Nantes improved & 5 & 180 & 332.02 & 16.9 & 0.2 & 0.2 & 0 & 10 \\
\hline Nantes improved & 5 & 180 & 332.02 & 16.9 & 0.2 & 0 & 0.2 & 37.3 \\
\hline Nantes improved & 5 & 180 & 332.02 & 16.9 & 0.5 & 0.5 & 0 & 6.7 \\
\hline Nantes improved & 5 & 180 & 332.02 & 16.9 & 0.5 & 0 & 0.5 & 62.6 \\
\hline Nantes improved & 5 & 370 & 332.02 & 16.9 & 1 & 1 & 0 & 10 \\
\hline Nantes improved & 5 & 370 & 332.02 & 16.9 & 1 & 0 & 1 & 46.7 \\
\hline Tam Tam & 5 & 370 & 440 & 22.3 & 0.2 & 0.2 & 0 & 6.7 \\
\hline Tam Tam & 5 & 370 & 440 & 22.3 & 0.2 & 0 & 0.2 & 38.8 \\
\hline Tam Tam & 5 & 370 & 440 & 22.3 & 0.5 & 0.5 & 0 & 0 \\
\hline
\end{tabular}




\begin{tabular}{|c|c|c|c|c|c|c|c|c|}
\hline Tam Tam & 5 & 370 & 440 & 22.3 & 0.5 & 0 & 0.5 & 30 \\
\hline Tam Tam & 5 & 180 & 440 & 22.3 & 1 & 1 & 0 & 0 \\
\hline Tam Tam & 5 & 180 & 440 & 22.3 & 1 & 0 & 1 & 26.7 \\
\hline Tam Tam & 5 & 180 & 332.02 & 16.9 & 0.2 & 0.2 & 0 & 6.7 \\
\hline Tam Tam & 5 & 180 & 332.02 & 16.9 & 0.2 & 0 & 0.2 & 56.7 \\
\hline Tam Tam & 5 & 180 & 332.02 & 16.9 & 0.5 & 0.5 & 0 & 6.7 \\
\hline Tam Tam & 5 & 180 & 332.02 & 16.9 & 0.5 & 0 & 0.5 & 43.3 \\
\hline Tam Tam & 5 & 180 & 332.02 & 16.9 & 1 & 0 & 0 & 3.3 \\
\hline Tam Tam & 5 & 180 & 332.02 & 16.9 & 1 & 0 & 1 & 23.3 \\
\hline Vilmorn & 5 & 180 & 332.02 & 16.9 & 0.2 & 0.2 & 0 & 6.7 \\
\hline Vilmorn & 5 & 180 & 332.02 & 16.9 & 0.2 & 0 & 0.2 & 36.7 \\
\hline Vilmorn & 5 & 180 & 332.02 & 16.9 & 0.5 & 0.5 & 0 & 3.3 \\
\hline Vilmorn & 5 & 180 & 332.02 & 16.9 & 0.5 & 0 & 0.5 & 28.2 \\
\hline Vilmorn & 5 & 180 & 332.02 & 16.9 & 1 & 0 & 0 & 3.3 \\
\hline Vilmorn & 5 & 180 & 332.02 & 16.9 & 1 & 0 & 1 & 23.3 \\
\hline Vilmorn & 5 & 180 & 332.02 & 16.9 & 0.2 & 0.2 & 0 & 10 \\
\hline Vilmorn & 5 & 180 & 332.02 & 16.9 & 0.2 & 0 & 0.2 & 53.3 \\
\hline Vilmorn & 5 & 180 & 332.02 & 16.9 & 0.5 & 0.5 & 0 & 6.6 \\
\hline Vilmorn & 5 & 180 & 332.02 & 16.9 & 0.5 & 0 & 0.5 & 44.4 \\
\hline Vilmorn & 5 & 180 & 332.02 & 16.9 & 1 & 1 & 0 & 3.3 \\
\hline Vilmorn & 5 & 180 & 332.02 & 16.9 & 1 & 0 & 1 & 30 \\
\hline us-Harumakigosum & 5 & 180 & 332.02 & 16.9 & 0 & 0 & 0 & 0 \\
\hline us-Harumakigosum & 5 & 180 & 332.02 & 16.9 & 0 & 0 & 0 & 0 \\
\hline us-Harumakigosum & 5 & 180 & 332.02 & 16.9 & 0 & 0 & 0 & 0 \\
\hline us-Harumakigosum & 5 & 180 & 332.02 & 16.9 & 0 & 0 & 0 & 0 \\
\hline us-Harumakigosum & 5 & 180 & 332.02 & 16.9 & 0.001 & 0 & 0 & 0 \\
\hline us-Harumakigosum & 5 & 180 & 332.02 & 16.9 & 0.01 & 0 & 0 & 14 \\
\hline us-Harumakigosum & 5 & 180 & 332.02 & 16.9 & 0.1 & 0 & 0 & 14 \\
\hline us-Harumakigosum & 5 & 180 & 332.02 & 16.9 & 1 & 0 & 0 & 0 \\
\hline
\end{tabular}




\begin{tabular}{|lcccccccc|}
\hline us-Harumakigosum & 5 & 180 & 332.02 & 16.9 & 10 & 0 & 0 & 0 \\
\hline us-Harumakigosum & 5 & 180 & 332.02 & 16.9 & 0 & 0 & 0 & 0 \\
\hline us-Harumakigosum & 5 & 180 & 332.02 & 16.9 & 0 & 0 & 0 & 0 \\
\hline $\begin{array}{l}\text { us- } \\
\text { Haru+A85makigosum }\end{array}$ & 5 & 180 & 332.02 & 16.9 & 0 & 0 & 0 & 0 \\
\hline $\begin{array}{l}\text { us- } \\
\text { Haru+A85makigosum }\end{array}$ & 8 & 180 & 332.02 & 16.9 & 0 & 0 & 0 & 0 \\
$\begin{array}{l}\text { us- } \\
\text { Haru+A85makigosum }\end{array}$ & 8 & 180 & 332.02 & 16.9 & 0 & 0 & 0 & 0 \\
$\begin{array}{l}\text { us- } \\
\text { Haru+A85makigosum }\end{array}$ & 8 & 180 & 332.02 & 16.9 & 0 & 0 & 0 & 0 \\
\hline $\begin{array}{l}\text { us- } \\
\text { Haru+A85makigosum }\end{array}$ & 8 & 180 & 332.02 & 16.9 & 0 & 0 & 0 & 0 \\
\hline $\begin{array}{l}\text { us- } \\
\text { Haru+A85makigosum }\end{array}$ & 8 & 180 & 332.02 & 16.9 & 0.001 & 0 & 0 & 0 \\
\hline $\begin{array}{l}\text { us- } \\
\text { Haru+A85makigosum }\end{array}$ & 8 & 180 & 332.02 & 16.9 & 0.01 & 0 & 0 & 14 \\
\hline $\begin{array}{l}\text { us- } \\
\text { Haru+A85makigosum }\end{array}$ & 8 & 180 & 332.02 & 16.9 & 0.1 & 0 & 0 & 14 \\
\hline $\begin{array}{l}\text { us- } \\
\text { Haru+A85makigosum }\end{array}$ & 8 & 180 & 332.02 & 16.9 & 1 & 0 & 0 & 0 \\
\hline $\begin{array}{l}\text { us- } \\
\text { Haru+A85makigosum }\end{array}$ & 8 & 180 & 332.02 & 16.9 & 10 & 0 & 0 & 0 \\
\hline $\begin{array}{l}\text { us- } \\
\text { Haru+A85makigosum }\end{array}$ & 8 & 180 & 332.02 & 16.9 & 0 & 0.1 & 0 & 0 \\
\hline $\begin{array}{l}\text { us- } \\
\text { Haru+A85makigosum }\end{array}$ & 8 & 180 & 332.02 & 16.9 & 0 & 1 & 0 & 0 \\
\hline
\end{tabular}

Table 2. The used mediums for embryogenesis in the lab 


\begin{tabular}{|c|c|}
\hline Medium & Composition of medium \\
\hline 1 & MS media containing $195.23 \mathrm{mg} / \mathrm{l} \mathrm{MgSO}{ }_{4}, 330.07 \mathrm{mg} / \mathrm{I} \mathrm{CaCl}_{2}, 18.3 \mathrm{mg} / \mathrm{l} \mathrm{MnSO}{ }_{4}$ \\
\hline 2 & MS media containing $195.23 \mathrm{mg} / \mathrm{l} \mathrm{MgSO}{ }_{4}, 330.07 \mathrm{mg} / \mathrm{I} \mathrm{CaCl}_{2}, 18.3 \mathrm{mg} / \mathrm{I} \mathrm{MnSO}_{4}+920 \mu \mathrm{l}$ 2,4-D \\
\hline 3 & MS media containing $195.23 \mathrm{mg} / \mathrm{IgSO}_{4}, 330.07 \mathrm{mg} / \mathrm{I} \mathrm{CaCl}_{2}, 18.3 \mathrm{mg} / \mathrm{I} \mathrm{MnSO}_{4}+32 \mu \mathrm{l} \mathrm{BAP}$ \\
\hline 4 & MS media containing $195.23 \mathrm{mg} / \mathrm{l} \mathrm{MgSO}_{4}, 330.07 \mathrm{mg} / \mathrm{l} \mathrm{CaCl}_{2}, 18.3 \mathrm{mg} / \mathrm{I} \mathrm{MnSO}_{4}+1750 \mu \mathrm{l} \mathrm{Kin}$ \\
\hline 5 & $\begin{array}{l}\text { MS media containing } 195.23 \mathrm{mg} / \mathrm{l} \mathrm{MgSO}_{4}, 330.07 \mathrm{mg} / \mathrm{l} \mathrm{CaCl}_{2}, 18.3 \mathrm{mg} / \mathrm{I} \mathrm{MnSO}_{4}+32 \mu \mathrm{l} \mathrm{BAP}+ \\
920 \mu \mathrm{l} \mathrm{2,4-D}\end{array}$ \\
\hline 6 & $\begin{array}{l}\text { MS media containing } 195.23 \mathrm{mg} / \mathrm{l} \mathrm{MgSO}_{4}, 330.07 \mathrm{mg} / \mathrm{l} \mathrm{CaCl}_{2}, 18.3 \mathrm{mg} / \mathrm{l} \mathrm{MnSO}_{4}+1750 \mu \mathrm{l} \mathrm{Kin} \mathrm{+} \\
920 \mu \mathrm{l} \mathrm{2,4-D}\end{array}$ \\
\hline 7 & $\begin{array}{l}\text { MS media containing } 195.23 \mathrm{mg} / \mathrm{l} \mathrm{MgSO}_{4}, 330.07 \mathrm{mg} / \mathrm{l} \mathrm{CaCl}_{2}, 18.3 \mathrm{mg} / \mathrm{l} \mathrm{MnSO}_{4}+32 \mu \mathrm{l} \mathrm{BAP}+ \\
1750 \mu \mathrm{K} \text { in }\end{array}$ \\
\hline 8 & $\begin{array}{l}\text { MS media containing } 195.23 \mathrm{mg} / \mathrm{l} \mathrm{MgSO}_{4}, 330.07 \mathrm{mg} / \mathrm{l} \mathrm{CaCl}_{2}, 18.3 \mathrm{mg} / \mathrm{I} \mathrm{MnSO}_{4}+32 \mu \mathrm{l} \mathrm{BAP}+ \\
1750 \mu \mathrm{Kin}+920 \mu \mathrm{l} \text { 2,4-D }\end{array}$ \\
\hline
\end{tabular}

Table 3: Statistics of NAA model for training vs. testing values

\begin{tabular}{|llllll|}
\hline \multicolumn{2}{|l}{ Training } & Data & \multicolumn{4}{l|}{ Testing Data } \\
\hline $\mathbf{R}^{\mathbf{2}}$ & RMSE & MBE & $\mathbf{R}^{\mathbf{2}}$ & RMSE & MBE \\
\hline $\mathbf{0 . 8 3 3}$ & 7.879734 & 0.311607 & 0.666 & 10.23974 & 3.78125 \\
\hline
\end{tabular}

Table 4. importance of parameters according to sensitivity analysis on the developed RBF model for embryogenesis

\begin{tabular}{|llllllllll|}
\hline Item & & \multicolumn{7}{c|}{ Input } \\
& Variety & Agar $(\mathrm{g})$ & $\begin{array}{l}\mathrm{MgSO}_{4} \\
(\mathrm{mg} / \mathrm{l})\end{array}$ & $\begin{array}{l}\mathrm{CaCl}_{2} \\
(\mathrm{mg} / \mathrm{l})\end{array}$ & $\begin{array}{l}\mathrm{MnSO}_{4} \\
(\mathrm{mg} / \mathrm{l})\end{array}$ & $\begin{array}{l}2,4-\mathrm{D} \\
(\mathrm{mg} / \mathrm{l})\end{array}$ & $\begin{array}{l}\mathrm{BAP} \\
(\mathrm{mg} / \mathrm{l})\end{array}$ & $\begin{array}{l}\text { Kin } \\
(\mathrm{mg} / \mathrm{l})\end{array}$ \\
\hline $\begin{array}{l}\text { VSR } \\
\text { Rank }\end{array}$ & 1.623392 & 0.999596 & 1.018606 & 1.019633 & 1.020771 & 1.558631 & 1.460148 & 1.310833 \\
\hline & 1 & 8 & 7 & 6 & 5 & 2 & 3 & 4 \\
\hline
\end{tabular}

Table 5. Importance of parameters according to optimization analysis on the developed RBF model for embryogenesis 


\begin{tabular}{|lllllllll|}
\hline Input & Agar $(\mathrm{g})$ & $\begin{array}{l}\mathrm{MgSO}_{4} \\
(\mathrm{mg} / \mathrm{l})\end{array}$ & $\begin{array}{l}\mathrm{CaCl}_{2} \\
(\mathrm{mg} / \mathrm{l})\end{array}$ & $\begin{array}{l}\mathrm{MnSO}_{4} \\
(\mathrm{mg} / \mathrm{l})\end{array}$ & $\begin{array}{l}2,4-\mathrm{D} / \mathrm{mg}) \\
\text { Variety }\end{array}$ & $\begin{array}{l}\mathrm{BAP} \\
(\mathrm{mg} / \mathrm{l})\end{array}$ & $\begin{array}{l}\text { Kin } \\
(\mathrm{mg} / \mathrm{l})\end{array}$ & Embryogenesis \\
\hline $\begin{array}{l}\text { Nantes } \\
\text { improved }\end{array}$ & 6.406556 & 195.23 & 330.07 & 18.3 & 0.46 & 0.032262 & 0.875449 & 62.5 \\
\hline
\end{tabular}

Figures
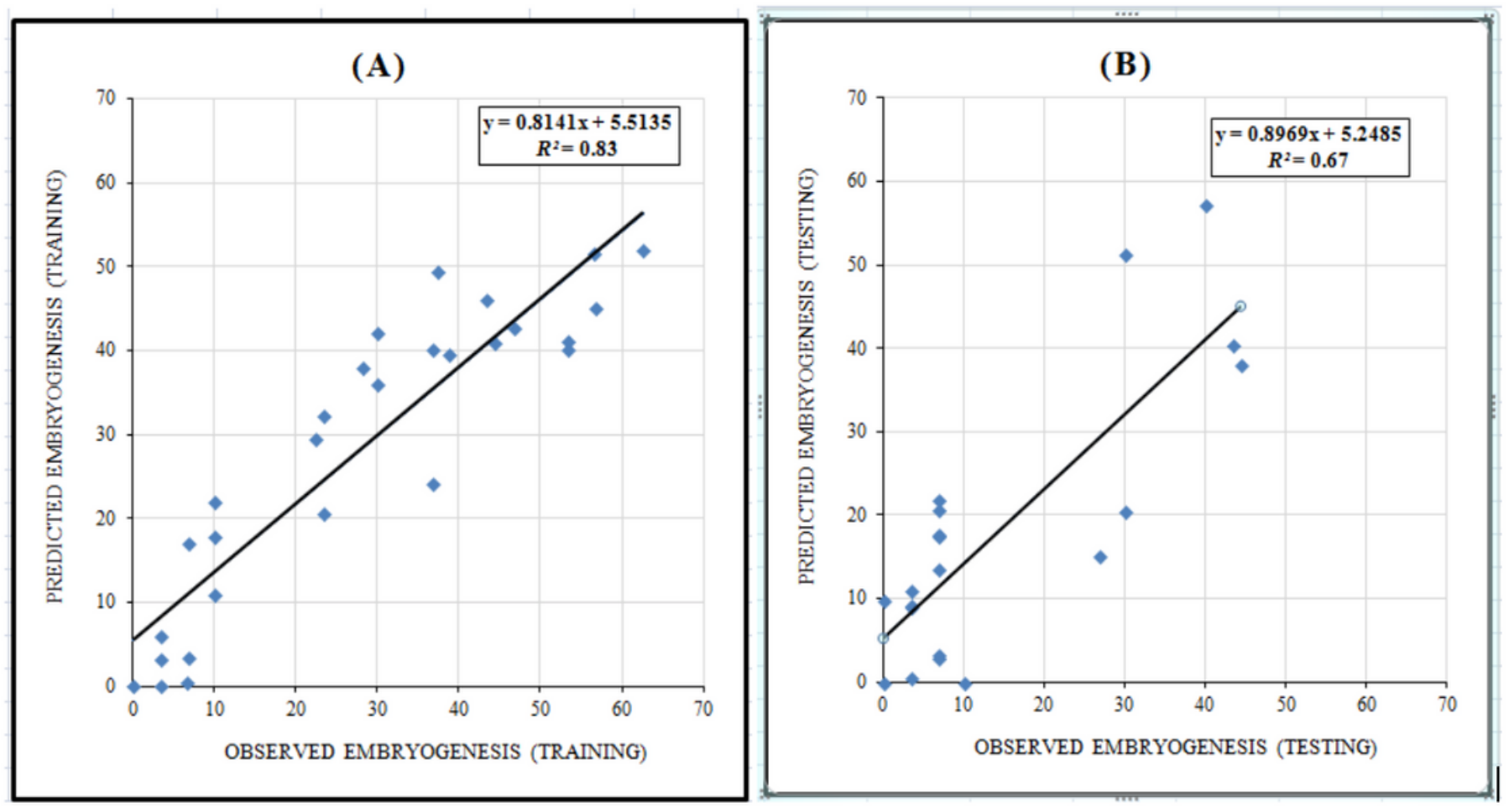

Figure 1

Observed vs. ANN model - predicted values of (A) training set; (B) Testing set. 


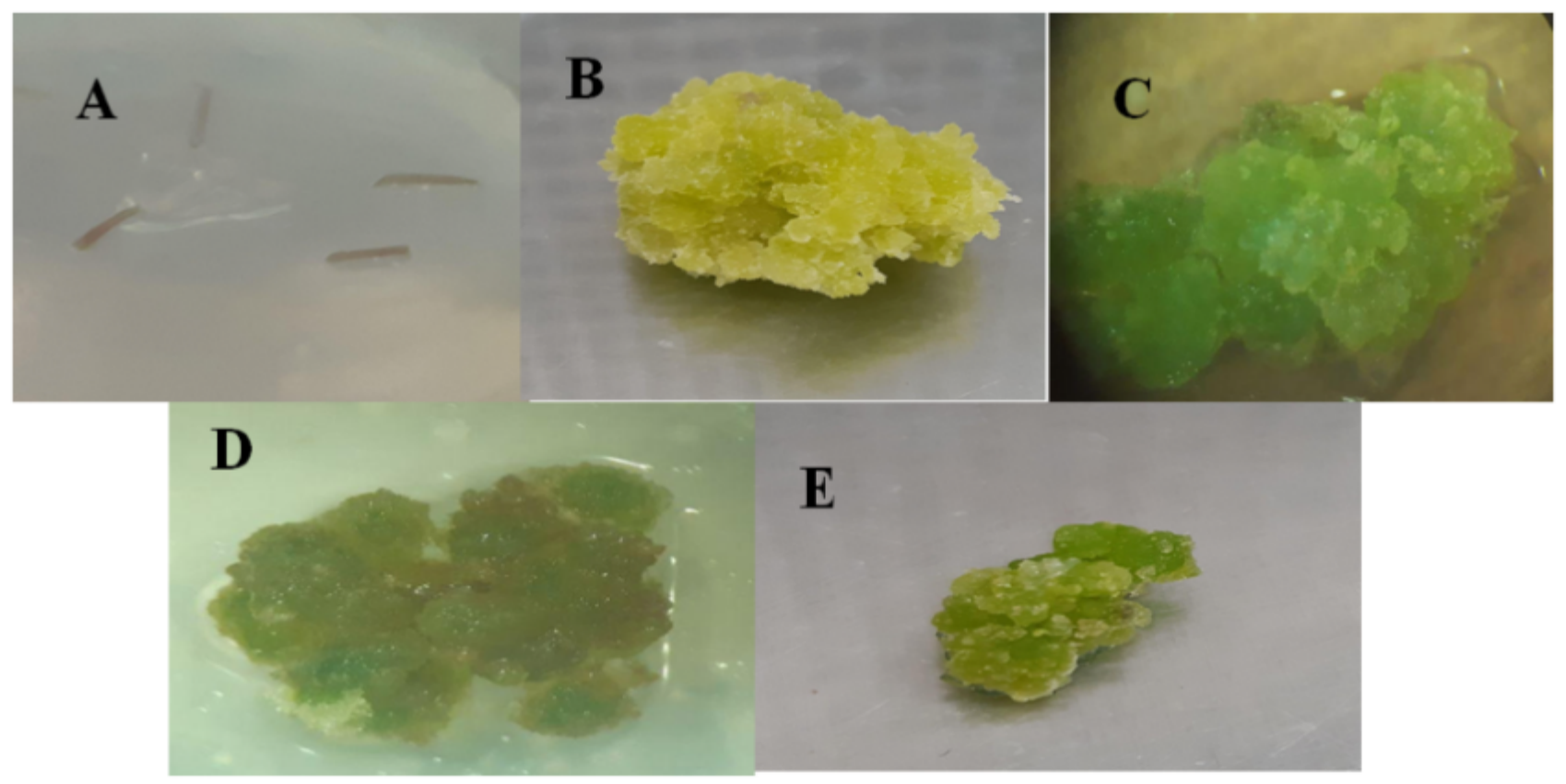

\section{Figure 2}

The embryos created of shoot explants in the MS media containing $195.23 \mathrm{mg} / \mathrm{l} \mathrm{MgSO}$, $330.07 \mathrm{mg} / \mathrm{l} \mathrm{CaCl}$, $18.3 \mathrm{mg} / \mathrm{l} \mathrm{MnSO} 4$ and containing plant growth regulators containing $0.46 \mathrm{mg} / \mathrm{l} 2,4-\mathrm{D}, 0.03 \mathrm{mg} / \mathrm{l} \mathrm{BAP}$ and 0.88 $\mathrm{mg} / \mathrm{l}$ kin. A: Shoot explants, B: Callus induction of shoot explants, C, D, E: Embryogenesis of shoot explants.

Percentage of embryogenesis

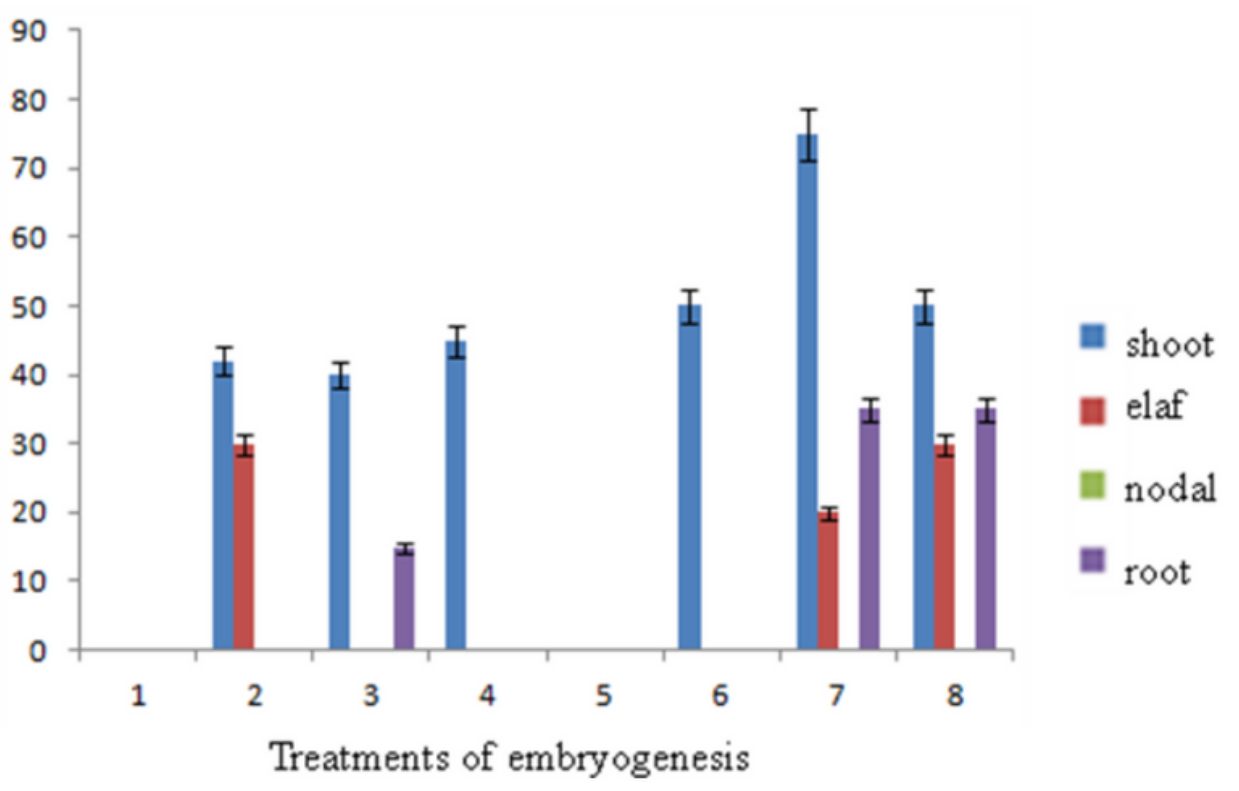

\section{Figure 3}

Percentage of embryogenesis after 5 weeks in different media 